\title{
The Erosion of Sovereignty ${ }^{*}$
}

\author{
Martin Loughlin
}

\section{Introduction}

Many of the assumptions underpinning the modern system of nation-states are now being placed in question. Increased global flows of capital, intensified networks of social interaction, and the emergence of transnational regulatory regimes on a significant scale are affecting the ability of national governments to regulate their economic conditions and improve their citizens' well-being. The effects of economic, technological and cultural change are having significant impacts on the activity of governing, the cumulative effect of which is experienced as a diminution in the efficacy of those levers of command and control that have been a common feature of the modern nation-state settlement. These developments have generated a great deal of policy analysis and scholarly examination.

It is not surprising to find such reviews regularly invoking the term 'sovereignty': the concept was, after all, shaped under conditions in which rulers turned inwards and sought to increase the intensity of their powers of rule, and today governments seeking to meet collective needs are increasingly obliged to focus their attention outwards and engage in co-operative inter-state ventures. This shift in orientation might indeed be having a significant impact on sovereignty. The problem is that many of those who claim that these developments are having a profound effect on the concept have failed adequately to explain its nature and significance.

Recent scholarly writing on sovereignty has been increasing at an exponential rate, virtually all of which asserts the need to re-work its meaning. ${ }^{1}$ There has, in particular, been a remarkable proliferation in the use of novel adjectival qualifiers: shared, mixed, divided, pooled, cooperative, floating, multiple, perforated, fragmented, reconfigured, complex, decentralized, agonal, and polymorphous are just some of the terms to have been affixed to the concept. ${ }^{2}$ But these 'innovative' studies seem only to generate deeper confusion. Some scholars have responded

* Earlier versions were presented at a workshop on 'Public Authority in an Era of Globalization' at the Whitlam Institute, University of Western Sydney in August 2013, in a lecture in the Faculty of Philosophy at Leuven University in February 2015, and at a Law Faculty seminar at the Hebrew University, Jerusalem in January 2016. I am grateful for the comments received on those occasions and also for discussions with my LSE colleagues: Damian Chalmers, Floris de Witte, Signe Larsen and Mike Wilkinson.

1 In 2009, Panu Minkkinen noted that, according to British Library records, around 330 books with sovereignty in the title have been published in the previous decade. Panu Minkkinen, Sovereignty, Knowledge, Law (London: Routledge, 2009), 6. The rate does not seem to be diminishing.

2 For more details see my paper 'Why Sovereignty?' in Sovereignty and Law: Domestic, Regional and International Perspectives, ed. Richard Rawlings, Peter Leyland and Alison L. Young (Oxford: Oxford University Press, 2013), 34-49. 
by suggesting that the concept should simply be abandoned. But if we are confused about what is being jettisoned, avoiding use of the concept is unlikely to improve the situation. And if, as I suggest, abandonment amounts to a rejection of the modern edifice of public law, then those making that case are obliged to offer an alternative conceptual architecture to explain governing authority today. This is a challenge few have recognized, and even fewer have sought to meet.

This paper therefore begins by outlining the concept of sovereignty that underpins the modern idea of law. In modern understanding, law is a product of political power and the special role performed by sovereignty is to stand as an expression of the autonomy of the political domain, by which is meant the distinctive way of understanding and engaging with the world grasped from the political point of view. Sovereignty signifies in jural form the essential relations of this political domain. In this sense, sovereignty is closely tied to the juristic concept of the state, understood as an institution that maintains supreme governing authority over a defined territory and which is to be differentiated both from its constituent people and its office-holders. State and sovereignty exist in a reciprocal relationship: state assumes sovereignty just as sovereignty assumes the state. Since these concepts of sovereignty and state are today much misunderstood, I start with a reprise of their meaning. Only with this clarification can the source of current confusion be identified and progress made in considering the impact of recent developments on the concept.

\section{Sovereign, sovereignty, state}

Considerable confusion exists today between the concept of sovereignty and the office of the sovereign. ${ }^{3}$ The term 'sovereign' denotes the office of the ruler, and it signifies the authority of that office. When the expression was first deployed, it was accepted that the sovereign ruler was not legally obligated to any other power; a medieval king who remained subject to the control of the Emperor was therefore not a sovereign ruler. Once the office of the sovereign ruler was recognized, it was accepted not only that the ruler's 'sovereignty' indicated independence from higher authority, but also that sovereignty signified the quality of the legal relationship between ruler and subject. The rightful authority of the sovereign ruler was absolute.

When in the early-modern period the ruler acquired more extensive governmental responsibilities, the representative nature of the office assumed a greater significance. Whatever the deference paid to the king's majesty, it was accepted that the ruler did not exercise a personal power. Recognition of the representative and therefore public - character of the office was achieved in circuitous fashion. Essentially, the monarchical image of the sovereign ruler was magnified and idealized. Once kingship took on the character of an ideal office, the way was open for the notion of 'the king's will' to become institutionalized. Idealization of the 
office was the precondition of its institutionalization. Institutionalization of the office of the sovereign led, in turn, to its corporatization. This was accomplished through internal differentiation. The 'sovereign' powers of government - what Bodin had called the 'marks of sovereignty'4 - no longer inhered directly in the person of the ruler, but came to be exercised variously through the king-in-parliament, the king-in-council, the king's ministers, and the king's courts. This principle could be seen most clearly at work in the British doctrine that the Crown-inParliament is sovereign, but institutionalization also occurred in so-called 'absolutist' regimes. Sovereignty came to mean the absolute legal authority of the ruling power in its corporate capacity.

These related processes - institutionalization, internal differentiation and corporatization of the office of the sovereign - made it necessary to distinguish between the sovereign powers of rule and the concept of sovereignty itself. Specifically, the powers of rule could be divided, but sovereignty - the absolute authority of the ruling power - could not. As Bodin was the first to note, the concept of sovereignty had to be differentiated from its marks - the 'sovereign' powers of government. The tasks of the office of the sovereign could certainly be divided, but sovereignty could not.

This distinction between sovereignty and governmental tasks reached a new stage once it came to be accepted that sovereign right was not bestowed from 'above' (by God), but was conferred from 'below' (by 'the people'). Secularization of the foundation myth ushered in a variety of claims about the ultimate source of authority under the banner of 'popular sovereignty'. But since 'the people' exist qua people only once institutional arrangements of governing have been established, this type of claim is paradoxical. One way this difficulty came to be finessed was by changing the nature of the argument. Shifting from a historic to a normative mode of argument, the search for an ultimate source of authority was re-packaged as a virtual act: the political pact, otherwise known as the social contract. This pact came to symbolize the passage from natural to civil or political existence, even though it acquires this meaning only in retrospect.

Once the virtual character of this transition is acknowledged, it is evident that, other than in a symbolic sense, power is not delegated from the people (the multitude) to their governors. Yet it is only through this type of virtual exercise that the juristic construction of the political domain - the world of public law - can be brought into being. Understood as such, sovereignty is a representation of the power and authority created through the formation of that worldview. Sovereignty vests neither in the ruler, nor in the office of government, nor in the people: sovereignty vests in the set of relations that are formed in instituting this political domain.

4 See Jean Bodin, The Six Bookes of a Commonweale [1576], trans. Richard Knolles 1606, ed. K. D. McRae (Cambridge, Mass: Harvard University Press, 1962), Bk I, ch. 10. 
The trajectory of development of this idea of absolute authority therefore moves from the establishment of a sovereign ruler, through the corporatization of the office, to a sense of sovereignty that is conceptually different from the actual institutional arrangements of government. Sovereignty now presents itself as a representation of the autonomy of the political/public domain; it expresses the absolute authority of that domain. This assertion of absolute authority involves a double juristic claim. First, this world of absolute authority (sovereignty) must assume an institutional form, and this is effected by conferring the office of government with a rightful power. Secondly, the power conferred equips government with unlimited competence to govern through the instrumentality of law. The first claim concerns the establishment of the authority of government by operation of political right (potestas); the second suggests that, through the operations of political right, an unlimited competence to govern by way of positive law is conferred (potentia).

Sovereignty, then, is simultaneously a political and a legal concept: it is the regulatory idea that enables us to conceive of an autonomous political domain and to grasp it in jural terms. As a representation of this autonomous domain, sovereignty might be compared to the double helix of DNA, in which the political and legal run as anti-parallel strands. The essential coding information of the political domain is contained within this structure, in which the political strand is powergenerational and the legal is power-distributive. This configuration of coding information contains the basic elements of state formation. The type of power with which we are here concerned is political power; this is power generated inter homines, power created as a result of the symbolic drawing together of a multitude into a 'people' or a 'nation' and harnessed through institutional forms. The most basic institutional formation is the state, a complex juristic entity comprising three essential aspects: territory, people, and ruling authority. ${ }^{5}$ And as a political domain it works according to an inclusionary/exclusionary dynamic in which political meaning is generated through a willingness to sacrifice individual interest to the collective good. ${ }^{6}$

In doctrinal terms, sovereignty expresses the principles of external independence, internal authority, and ultimate legal supremacy of the state. A people occupying a defined territory and equipped with institutions of self-rule presents itself to the rest of the world as a sovereign entity, signifying its independence from subjection to any higher authority. This principle forms the basis of international law, a sphere in which states contract with one another to regulate inter-state relations. ${ }^{7}$ Although it is sometimes said that the existence of a body of interna-

5 See Loughlin, Foundations, ch. 7.

6 See Carl Schmitt, The Concept of the Political, trans. George Schwab (Chicago: Univ. of Chicago Press, 2007); Bertrand de Jouvenel, The Pure Theory of Politics (Cambridge University Press, Cambridge, 1963); Paul W. Kahn, Putting Liberalism in its Place (Princeton: Princeton University Press, 2005).

7 See, e.g., UN Charter (1945), Art. 2, which recognizes the 'sovereign equality', 'territorial integrity' and 'political independence' of all states. 
tional law itself amounts to a limitation on state sovereignty, this is confused. States may have pledged to restrict the exercise of some of their governmental powers - their 'sovereign rights' - but this is not the same as a restriction on sovereignty. States sign and ratify treaties as sovereign entities: international law, far from being a limitation is in reality an explication of state sovereignty.

A similar point can be made with respect to internal authority. Sovereignty is an essential characteristic of a state. Every sovereign state possesses supreme, unlimited and indivisible authority. There can be no limitation on a state's authority to rule by means of law. In most regimes, constitutional rules allocate the 'sovereign rights' of rule - the 'marks of sovereignty' - among particular institutions of government, generally between legislature, executive and judiciary. Since the jurisdictional competence of each of these governmental institutions is established and limited by a formal constitution, none possess ultimate authority to rule. But this distinction does not amount to a limitation on sovereignty. British scholars wedded to the traditional principle of the absolute legal authority of the Crown-in-Parliament, in particular, have a tendency to become confused on this matter. In modern constitutional regimes, the ultimate sovereign authority becomes an abstract entity: 'the people' or 'the Nation', which is the bearer of 'constituent power'. ${ }^{8}$ Constitutional arrangements do not limit or restrict sovereignty. They exemplify the existence of sovereignty.

If sovereignty is a representation of the autonomy of the political domain, then we can appreciate how it is effectively a synonym for the juristic concept of the state. From a juristic perspective, the state is the entity that offers access to modern political reality. The state may be defined as an autonomous entity comprising three constituent elements of territory, people and institutional form. In a juristic sense, however, the state is better grasped as a scheme of intelligibility. As an institution, it is both an idea and its instantiation, but it cannot be reduced to any of its constituent parts. Through an exercise of representation, it brings into existence a comprehensive way of seeing, understanding and acting in the world.

This point was clearly understood by Michel Foucault who recognized that political reason involves 'a different way of thinking [about] power, the kingdom, the fact of ruling and governing; a different way of thinking [about] the relations between the kingdom of Heaven and the kingdom on Earth'. Political reason 'delineated the state as both its principle and its objective, as both its foundation and its aim'. He concluded that the state must be understood to be 'a principle of intelligibility and strategic schema, or, to use an anachronistic word ... a regula-

8 I here set to one side the complicated - and contextual - question about the existence of a sovereign in this type of constitutional regime. The constitutional arrangements may govern in normal times, but that does not cover the situation of an exception in which extraordinary action must be taken as a matter of the state's self-preservation. Only at these moments might a sovereign reveal itself, hence Schmitt's claim that sovereign 'is he who determines on the exception'. See Carl Schmitt, Political Theology: Four Chapters on the Concept of Sovereignty, trans. George Schwab (Chicago: University of Chicago Press, 2005), 5. But see also section 6 below. 
tory idea'. ${ }^{9}$ The state is, in other words, 'the regulatory idea of governmental reason'. ${ }^{10}$ This concept of the state enables us to grasp the ways in which inherited institutions and practices form an autonomous set of relations. The state is 'the principle of intelligibility of an absolutely given reality, of an already established institutional whole'. ${ }^{11}$ The state is absolute because it 'is organized only by reference to itself: it seeks its own good and has no external purpose'. ${ }^{12}$ In particular, 'no positive law, of course, no moral or natural law, and in the end perhaps no divine law - but this is another question - at any rate, no law can be imposed on the state from the outside'. ${ }^{13}$

Foucault's idea of the state owes a great deal to Hegelian philosophy, and it is clearly expressed in Bosanquet's treatise on the theory of the state. Bosanquet follows Hegel in arguing that the state is 'not merely the political fabric' but 'includes the entire hierarchy of institutions by which life is determined, from the family to the trade, and from the trade to the Church and the University'. ${ }^{14}$ The state, Bosanquet writes, is 'the structure which gives life and meaning to the political whole'; it therefore is not a person or a number of persons but 'a working conception of life'. ${ }^{15}$ Recognizing the juristic character of this claim, Bosanquet similarly notes the necessity of embracing law as Recht, since this 'maintains the connection between the law and the spirit of the law' and 'prohibits the separation between positive law, and will, custom or sentiment'. ${ }^{16}$

\section{An infinite labyrinth of errors}

Sovereignty is much misunderstood today largely because of its intrinsic political and legal dimensions. It is a fundamental concept in both political and legal thought, since it expresses the autonomous nature of the state's political power and its specific mode of operation in a distinctively juristic form. It is the concept on which received ideas of legitimate domination are founded. Those ideas have always been contested, not least because they involve the continuous struggle to establish the conditions of political authority in regimes founded on collective self-actualization. Today, however, the problem is that the contest over the conditions of legitimate domination is now being equated with the contestability of the concept of sovereignty itself. This leads to the misuse of language, generating

9 Michel Foucault, Security, Territory, Population: Lectures at the Collège de France, 1977-78, trans. Graham Burchell, ed. Michel Senellart (London: Palgrave, 2007), 286.

10 Ibid.

11 Ibid., 286-7.

12 Ibid., 290.

13 Foucault, Security, Territory, Population, 290.

14 Bernard Bosanquet, The Philosophical Theory of the State [1899] 4th ed. (London: Macmillan, 1923), 140.

15 Ibid., 140-1. Bosanquet's concept of sovereignty follows on similar lines. Hence, sovereignty 'resides in no one element' of the state but is essentially 'the relation in which each factor of the constitution stands to the whole'. Sovereignty 'resides only in the organised whole acting qua organised whole'. Ibid., 262. 
analytical confusion, misdiagnosis of the issues, and even incoherence of proposed solutions. One reason for this is that during the twentieth century the dual legal and political dimension became a source of deep discomfort for scholars in the emerging academic disciplines of political science and law.

In their quest for scientific credibility, political scientists have been seeking to discover causal laws of political behaviour and, within such an empiricist mindset, sovereignty was felt to express the metaphysics of a bygone era. To the extent that political scientists continue to invoke the concept, they tend to conflate sovereignty and government. This is because of a failure to maintain the distinction between the concept and its particular 'marks'. Sovereignty expresses a principle of unity: it is an expression of illimitability, perpetuity and indivisibility. Any limit on sovereignty eradicates it, any division of sovereignty destroys it. Yet the powers of rule, the 'marks of sovereignty', not only can be divided and limited: for the purpose of generating political power and maintaining political authority, they must be so divided and limited. But this is a maxim relating to the phenomenon of governing, not to the concept of sovereignty.

This distinction between sovereignty and government forms a central pillar of public law thought. In Book II of his Six livres de la république, Bodin explained that there is a 'great difference between the state and the government of the state'. ${ }^{17}$ It has since been treated as a commonplace of public law thinking. Bodin contended that the distinction 'seems to me more than necessary for the good understanding of the state of every commonwealth, if a man will not cast himself headlong into an infinite labyrinth of errors' ${ }^{18}$ Having forgotten the point of this distinction, this is precisely what now is happening.

Some errors are of the most elementary kind, as in the claim that federalism is incompatible with - or (the same thing) requires a division of - sovereignty. But mostly they arise because political scientists fail to acknowledge that sovereignty is a juridical concept. As a result, they confuse sovereignty with governmental competence, and therefore with ideas such as autarky, that is, with the ability of a nation-state to control its own material conditions and destiny. This stems from a blurring of the distinction between the ability to govern and the right to govern. This distinction relates to two different concepts of power: the former is potentia, the actual ability to control things, while the latter is potestas, the exercise of rightful authority. Political scientists tend to focus only on the former, whereas the latter is the critical aspect of the concept of sovereignty. Sovereignty involves the dialectical interplay between potestas and potentia, right and capacity.

At the same time as political scholars were seeking to burnish their scientific credentials, legal scholars, determined to establish the autonomous normative authority of law, were devoting their energies to the severance of any significant connection between law and political power. To the extent that lawyers continue 
to invoke the concept of sovereignty, they seem increasingly to be using it in a purely metaphorical sense, as the 'sovereignty of law'. This is in reality an attempt to overthrow the concept. In place of sovereignty and state, they assert the autonomy of law or constitution; this amounts to more or less the same thing since in this formulation 'constitution' stands merely as an ideal representation of legal form. The concept of law is here converted into an abstract entity called 'legality', a concept that not only is autonomous but also contains its own intrinsic morality and from which it derives its own source of authority. ${ }^{19}$ Those who assert the autonomy of constitution rather than legality draw a distinction without a difference: these theories are variants of normativism, united in the abstract and ideal character of the directing idea of the autonomy of normative ordering.

Some jurists have explicitly recognized that this line of argument effects a 'paradigm shift' in public law. It requires the overthrow of 'the conventional statist paradigm' and its replacement with the 'cosmopolitan paradigm'. ${ }^{20}$ If law is to be conceived as a normative order whose authority comes not from the state and not from sovereign authority but from its intrinsic moral properties, then it is obvious not only that the connection between law and political reason is sundered but also that no clear distinction can be drawn between the law of a state and international law. The claims of state sovereignty, it is asserted, must be rejected and in its place a monist system of law, in which there is a single universal legal order from which the validity of municipal legal orders derive, is postulated.

This innovation remains controversial, not least in being a theory of law far removed from the (political) world we inhabit. But it also contains a basic theoretical difficulty: it postulates a system of law as a normative scheme that somehow carries its own authority. The problem here is that norms do not of themselves act; legal norms acquire their authority only within the frame of a political power that ensures their application and enforcement. This political aspect of sovereignty expresses the essential factual conditions that underpin legal validity. It is this aspect that normativists seek to suppress.

\section{The eclipse of sovereignty?}

To this point, I have tried to show that sovereignty is a foundational concept for public law, that the challenge for those who have sought its overthrow is immense, and that those who have advocated its overthrow have either failed to

19 See, e.g., David Dyzenhaus, 'Constitutionalism in an old key: legality and constituent power,' Global Constitutionalism 1 (2012): 229-60; David Dyzenhaus, 'The Question of Constituent Power,' in The Paradox of Constitutionalism: Constituent Power and Constitutional Form, ed. Martin Loughlin and Neil Walker (Oxford: Oxford University Press, 2007), 129-45.

20 Mattias Kumm, 'The Cosmopolitan Turn in Constitutionalism: On the Relationship between Constitutionalism in and beyond the State,' in Ruling the World? Constitutionalism, International Law and Global Governance, ed. Jeffrey L. Dunoff and Joel P. Trachtman (Cambridge: Cambridge University Press, 2009), 258-324. 
grasp its foundational nature or have avoided the problems raised by their proposed re-specification. There is, however, one jurist who did address this juristic challenge in a systematic manner and whose work is worth considering in some detail. This is the early-twentieth century French public lawyer, Léon Duguit. Following through the logic of emerging positivist social science, Duguit maintained that the processes of continuing social evolution that were leading to the establishment of an administrative state had rendered the modern (post-revolutionary) public law inheritance anachronistic. The entire scheme of public law founded on the principle of sovereignty, he argued, was being eclipsed. It needed to be reconstituted on a new foundation. ${ }^{21}$

Duguit claimed that the modern settlement of public law rested on two basic principles: state sovereignty, expressed primarily as the legal personality of 'the nation'; and individual autonomy, resting on the natural, imprescriptible rights of the individual. As a consequence, public law is founded on the creation of two primary subjects: the juristic person that formulates laws or commands (the sovereign/state) and its subjects who are obliged to obey (individuals). He noted that the state expresses the general will of citizens and therefore seeks to organize itself so as to ensure maximum protection of individual subjective rights. But he also recognized that although the individual is a bearer of rights, the collective person is superior to the individual person: the will of (the legal person of) the state is superior to the individual will.

This entire modern scheme of public law, Duguit asserted, rests on a mere fiction: not only is the idea of a general will fictitious but, since humans are social beings, so too is the assertion of the natural rights of the individual. If public law is to be grasped in scientific terms, this subjectivist system founded on sovereignty must be replaced by an objective jural principle. This objective principle is the principle of social solidarity. The authority of government thus derives not from rights but from duties. In reality, governments do not exercise the sovereign right to issue commands; their authority is based on the duties they perform. The 'real basis' of governmental authority is founded on the fact of 'social interdependence', and this has the consequence that there is 'an intimate relation between the possession of power and the obligation to perform certain services'. ${ }^{22}$ What follows, Duguit maintained, is that 'public service' replaces sovereignty as the foundation of modern public law.

Duguit argued that once the significance of public service is recognized, 'a rigorously objective order' is instituted and it is 'controlled by principles equally imposed on the government and its subjects'. ${ }^{23}$ The objective law is that which 'serves the public need and secures the co-ordination of modern corporate life'. ${ }^{24}$

21 Léon Duguit, Les transformations du droit public (Paris: Armand Colin, 1913); in English translated ad as Law in the Modern State, trans. Frida and Harold Laski (London: Allen \& Unwin, 1921) [subsequent page references are to the English edition].

22 Duguit, Law in the Modern State, 43, 44.

23 Ibid., 54.

24 Ibid., 118. 
With the emergence of the modern administrative state, the sovereign right of command is replaced by the principle of organization as the basis of public law. Sovereignty is 'eclipsed' and is superseded by 'the formation of an objective governmental duty in regard to public services, the operation of which is legally guaranteed'. ${ }^{25}$

In this scheme of authority, the status of any legal rule is the product not of its source but of its function. Constitutional law is not fundamental because of its pedigree but because the object of this body of law 'is to give the state the best means of serving social needs' ${ }^{26}$ The significance of the claim to the primacy of this functional principle is radical. It suggests that no clear distinction is to be drawn between statute, executive decrees and administrative rules. Such a distinction is based on a formal hierarchical understanding which has its justification in the fiction of sovereign will; this type of distinction must now be supplanted by an assessment of purpose. ${ }^{27}$ All legal acts thus become equally reviewable in the light of the 'objective law'.

Duguit offers a theory of public law founded on the entire eclipse of sovereignty. It develops the juristic implications of the social scientific theories of SaintSimon, Comte and Durkheim, which maintains that society evolves through three main stages: the theological stage, followed by the metaphysical stage, eventually leading to the scientific stage. Sovereignty is claimed to be a product of the metaphysical era's borrowing from the theological and it has no place in the scientific era that is emerging. Modern society should no longer be viewed through the prism of individual and state; society must be conceived as a collection of groups and the key task for government is to provide some sound method for coordinating their activities. Following this line of analysis, the predominant legal mode of operation shifts from that of command to co-ordination. One consequence is that the juridical logic of legal/illegal is supplanted by the disciplinary logic of proportionate/disproportionate.

The emergence of objective social law also has implications for understanding the boundaries between national and international law, boundaries which had previously been recognized through concepts of state and sovereignty. Once determinate social groups (sc., nation-states) are organized in accordance with the discipline of objective law, bonds of solidarity are formed across groups, and these evolve into a type of 'intersocial law', an embryonic form of modern international law. ${ }^{28}$ With the growing interdependence between members of different social groups, a sentiment of intersocial justice emerges and through the 'double sentiment of intersocial sociality and intersocial justice' international juridical norms are created. The authority of these norms does not rest on promulgation by supe-

28 Léon Duguit, 'Objective Law,' Columbia Law Review 20 (1920): 817-31 (Pt.I); Columbia Law Review 21 (1921): 17-34 (Pt.II); 126-43 (Pt.III); 242-56 (Pt. IV). See (Pt IV), 250. 
rior will: it rests 'on the consciousness existing in the individuals to whom it applies that this rule should be furnished with a sanction by compulsion'. ${ }^{29}$ International law, Duguit argues, now establishes objective (social) norms that governments of all nation-states are obliged to respect.

The great value of Duguit's theory is to have presented the implications and underlying assumptions of his 'eclipse of sovereignty' thesis in a more systematic manner than those who today claim that we are entering an era of 'post-sovereignty'. It is not difficult to identify the developments that ground contemporary claims: since government is ubiquitous and functions mainly through an administrative modality, modern constitutional assumptions rooted in Enlightenment ideas of 'limited government' authorized by 'the people' are undoubtedly becoming strained. But unlike Duguit's theory, which offers a systematic juristic analysis rooted in sociological positivism and underpinned by a specific argument about scientific progress, these elements are invariably absent in those making similar claims about sovereignty today.

Failing to acknowledge the juristic nature of sovereignty, the former group conflates sovereignty with the ability of a nation-state fully to control the material conditions of its existence. There is no doubt that in contemporary conditions governments are obliged to co-operate with other actors, both within the nationstate and beyond. But as has already been explained, sovereignty is not an aggregation of competences. Competence concerns capacity, whereas sovereignty incorporates an intrinsic dimension of 'right'. Once this is recognized, the empirical assessment about the complexity of contemporary governmental networks can be accepted without it following that public law has entirely lost its symbolic power. The modern discourse of public law seeks to manage the tensions between the conceptual and empirical: it aims not only to identify the formal right to rule but also to specify conditions that maintain the capacity to rule. Consequently, while it can be accepted that the intricacy of contemporary governing arrangements imposes strains on the ability to manage these tensions, it is not obvious that this world of representation must now be treated merely as a façade masking the realities of power networks operating in the world today. Those who do seek to draw this conclusion are obliged to argue, it would appear, that we are now living in a post-jural world.

These arguments are mostly made by scholars who maintain that governmental developments have undermined the normative scheme of modern public law, 
such that we are now living in a world of ubiquitous governmentalism. ${ }^{30}$ But there are also certain jurists who make an almost opposite manoeuvre and accentuate the normative to the neglect of the empirical. This latter type of post-sovereignty claim founds itself on the argument that legal principles have now evolved beyond the site of the nation-state in which they were originally situated and should now be recognized as establishing a set of self-sustaining universal principles of constitutionality. Whereas the post-sovereignty argument made from the perspective of governmentality is that law has become entirely instrumentalized and has thereby lost its structural connection to legitimacy, the argument from hyper-constitutionality is that the concept of legality is now to be fused with legitimacy.

Those making the claim of hyper-constitutionality reject the idea that sovereignty constitutes a representation of the autonomy of the political realm, anchored by the political unity of a people or state. They argue instead that modern (i.e. liberal, rights-protecting) constitutions are constitutive of legality and, accepting the universality of the principles of liberty and equality they appear to contain, that this corpus of constitutional principles now possesses freestanding authority. ${ }^{31}$ This is a thoroughly normativist argument which, although it signals the emergence of an important phenomenon - the rise of international 'juristocracy' - it otherwise does not bear a strong relation to the realities of today's political world.

Duguit's radical analysis focuses on the juristic challenges presented by the growth of administrative government. The administrative developments he documents are undeniable, but his argument that this leads to an eclipse of sovereignty is overstated. The emergence of an 'objective social law' - 'do what you must to promote social solidarity' - is a significant innovation. From the vantage point of the twenty-first century, however, it is evidently an account which is presented as social science but is underpinned by a collectivist political ideology. His objective law accentuates the claims of capacity but underplays those of political right, that is, the symbolic in the constitution of political authority. It envisages a world of potentia without potestas: there is no established 'right' to govern and the

30 This is the type of claim made by Foucault in his analysis of gouvernementalité. See Michel Foucault, 'Governmentality,' in Foucault, Essential Works, vol. 3, ed. James D. Faubion (London: Penguin, 2000), 201-22. In 1976, Foucault had argued that 'political theory has never ceased to be obsessed with the person of the sovereign'. The concepts of sovereign, law, and prohibition, he maintained, established a system of representation of power which was bolstered by theories of right. This, he claimed, was now anachronistic and what was needed is a political theory that does not revolve around the issue of sovereignty and prerogative: 'We need to cut off the king's head'. See Michel Foucault, 'Truth and Power,' in Foucault, Power: Essential Works of Foucault, 1954-1984 (London: Penguin, 2001), vol. 3, 111-33, at 122.

31 See, e.g., Mattias Kumm, "Who is Afraid of the Total Constitution? Constitutional Rights as Principles and the Constitutionalization of Private Law,' German L. J. 7 (2006): 341-69; Kumm, 'The Cosmopolitan Turn in Constitutionalism,' 258-324; Mattias Kumm, 'The Best of Times and the Worst of Times: Between Constitutionalism Triumphalism and Nostalgia,' in The Twilight of Constitutionalism?, ed. Petra Dobner and Martin Loughlin (Oxford: Oxford University Press, 2010), ch. 10. 
only justification for the exercise of governmental power is derived from the ends it pursues. The hyper-constitutionality argument, by contrast, promotes an argument of right that over-emphasizes the autonomous authority of legality and under-emphasizes the continuing power of the political dimension to sovereignty.

\section{The erosion of sovereignty in the EU}

The contemporary movements of governmentalism and hyper-constitutionalism are exaggerated and contradictory. But by highlighting the emerging tensions between right and capacity in the constitution of authority, they direct us towards the critical contemporary issues. The claim that sovereignty has now been eclipsed may be overstated but this is not to say that the concept remains unaffected by the trajectory of governmental developments. The threat is real but it is clarified only once misconceptions surrounding the concept of sovereignty have been removed. In the face of the misunderstandings outlined, it is tempting to retreat to a formal juristic account of sovereignty and maintain that changes at the level of governmental organization do not of themselves affect the concept of sovereignty: whenever there exists a sovereign ('the people') that possesses the 'constituent power' to legislate to alter existing governmental arrangements, the concept remains untouched. This, however, is a less than satisfactory response, not least because sovereignty has both legal and political dimensions. Since sovereignty expresses a relation between right and capacity, there may come a point when developments at the level of governmental organization impose such strains on the right-capacity nexus that sovereignty is unable to carry its meaning as a representation of the autonomy of the political realm. This is the critical issue. But it is better expressed not as an eclipse - a situation in which, because of some development, sovereignty disappears from view - but an erosion, a process of gradual diminution and loss in the meaning of the concept.

This argument can be advanced by first taking a relatively straightforward case, one which delineates the boundaries to the exercise of sovereign authority of a state. This is the case of a colony that acquires its independence from an imperial power. It is an easy case because it explains how, rather than eroding sovereignty, this development - which appears as a loss of sovereignty - in fact exemplifies the way in which modern understandings operate. In a formal sense, de-colonization signifies a revolutionary break, the effect of which is to extinguish any sovereign right the imperial authority once possessed with respect to that territory. The former colony takes its place in the world as a newly-established sovereign state, recognized as such by other sovereign states. But what if the imperial power seeks subsequently to re-assert its rule? If sovereignty is absolute, perpetual and illimitable, this re-assertion must be within the right of the imperial power. Yet we might surmise that any such attempt to assert authority over the former colony is likely to be ineffective. The right-capacity nexus demonstrates why. 
It might be noted, first, that once the subjects and officers of this new independent state have signalled allegiance to their new constitution and this state is recognized as such in international law, the former imperial power is unable any longer to assert a claim of right (potestas). But it is also the case that the break is likely also to destroy the imperial power's capacity (potentia) to re-establish its authority to rule. The reason is that, without a claim of right, any action to acquire governing power will be regarded by the relevant parties not as a re-assertion of legitimate domination but simply as the expression of naked force. Since sovereign authority rests on the dialectical interplay between potestas and potentia, this requires, at a minimum, some acceptance by subjects. Without this, the sovereign authority once exercised by the imperial power is, in the act of decolonization, effectively destroyed.

The straightforward case of decolonization helps to highlight the complexities revealed by contemporary governmental configurations that blur the distinction between national sovereign authority and the claims of international law. These are most clearly illustrated in the evolving arrangements of the European Union. Many of the recent confusions in the treatment of sovereignty have arisen in the context of such discussion and much of the literature about limited, divided etc. sovereignty has been generated in this context. It is with respect to this site of analysis that some scholars have claimed that the current configuration of European nation-states signals the emergence of a world of 'post-sovereignty'.

This claim is most forcefully made by Neil MacCormick, who argues that since no nation-state in the EU is in 'a position such that all the power exercised internally in it, whether politically or legally, derives from purely internal sources', none can be regarded any longer as a sovereign state. ${ }^{32}$ MacCormick amplified his analysis by claiming that 'absolute or unitary sovereignty is entirely absent from the legal and political setting of the European Community' on the ground that 'neither politically nor legally is any member state in possession of ultimate power over its own internal affairs'. ${ }^{33}$ Yet one can accept that the EU 'exercises political power on some matters over member states' and that EU legislation 'binds member states and overrides internal state-law within the respective criteria of validity' ${ }^{34}$ without it following that 'ultimate' authority ceases to remain within the member states. The elaborate inter-governmental arrangements of the EU have been created by its member states to meet the collective needs of their citizens. Unless the argument is that this arrangement is now permanent, such that it is no longer within the political authority of a member state to exercise the procedure for withdraw from these treaty arrangements, ${ }^{35}$ then no issue of ultimate authority and no question of sovereignty - is involved. This is an argument that no jurist has yet made. In fact, the argument about so-called 'unitary sovereignty' makes

32 Neil MacCormick, 'Beyond the Sovereign State,' Modern Law Review 56 (1993): 16.

33 Neil MacCormick, Questioning Sovereignty: Law, State, and Nation in the European Commonwealth (Oxford: Oxford University Press, 1999), 132.

34 MacCormick, Questioning Sovereignty, 132.

35 See Art. 50, TEU. 
little sense: it suggests that sovereignty is destroyed whenever a state adopts a federal system of government, or even when it adopts a modern entrenched constitution that allocates governmental competences among a variety of institutions.

Alongside this specifically legal positivist confusion, there exists a more general ambiguity in the European literature concerning the distinction between sovereignty and government. Much of this stems from an early ruling of the European Court of Justice which claimed that the arrangement 'creates a new legal order ... for the benefit of which the States have limited their sovereign rights, albeit within limited fields'. ${ }^{36}$ The first aspect presents no conceptual difficulties. Any number of legal orders can exist within the frame of a sovereign state. This is, after all, exemplified in the United Kingdom as well as being a critical aspect of federal systems. All that is required is for the sovereign authority to have established procedures for determining spheres of competence and rules of priority. Confusion arises because of the Court's reference to 'sovereign rights'. But this term simply means 'powers of government'. Certain powers of government - governmental competences - have undoubtedly been limited, restricted and pooled as a consequence of EU membership, just as certain powers of government are limited, restricted and pooled whenever a state enters into any treaty. Again, this has no direct bearing on sovereignty. ${ }^{37}$

The distinction between competences and sovereignty must be kept clear: competences can be limited, sovereignty cannot. Sovereign authority resides in the ultimate power of the people to determine the form of constitution of the state, and this can entail membership of the EU or withdrawal from it. Those who argue that the existence of EU law operating on the principle of primacy within the sphere of EU competence imposes a limit on sovereignty have it the wrong way round. Rather, as successive rulings of the German Federal Constitutional Court have indicated, it is the sovereignty of member states that impose limits on the competence of the EU. Far from limiting, dividing or decentralizing sovereignty, the obligations that a state assumes through treaties are manifestations of its continuing sovereign authority.

The distinction between sovereignty and its marks brings us to the crux of the matter concerning sovereignty within the EU. Bodin identified as the principal 'marks of sovereignty' the right to make laws, to declare war and make peace, appoint magistrates, determine controversies, pardon, coin money, establish weights and measures, and to impose taxes. ${ }^{38}$ The critical question is: if an elabo-

36 Case 26/62, Van Gend en Loos v. Nederlandse Administratie der Belastingen [1963] ECR 1, 12.

37 Although the Court of Justice of the EU has stated that, given the principle of the supremacy of EU law, it is for EU law to determine the relationship between national law and member law, this operates only at the level of interaction of legal orders. Those who suggest that this affects sovereignty are in reality adopting a type of legal normativism that aims altogether to displace the concept.

38 See Bodin, Six Bookes, Bk I. ch. 10. See also Thomas Hobbes, Leviathan, ed. Richard Tuck (Cambridge: Cambridge University Press, 1996) ch. 18. 
rate governing network has been instituted such that the bearers of sovereignty ('the people') retain the formal right but no longer possess the effective capacity to alter governmental arrangements then has sovereignty been eroded of meaning? Does the formation of governmental arrangements that can no longer easily be explained as exercises of the will of a sovereign people and can no longer easily be repealed by a sovereign people signify stages in the erosion of sovereignty?

At the level of general international law, this type of evolution can be seen in the creation of elements of international law that do not derive from the will of states. This is exemplified by the emergence of ius cogens and obligations erga omnes, that is, by the establishment of norms that bind even when their validity is rejected by certain states. Subjective right, based on the capacity of states to contract their international obligations, is to this extent being superseded by objective law that is not promulgated by the treaty-making authority of states but by a new entity which, for want of a better term, is commonly labelled the international community'. Even-handed enforcement of these norms remains the weakest aspect of this development, which suggests that presently this development is susceptible to being used as an instrument of domination. One illustration is provided by the establishment of International Criminal Tribunals relating to former Yugoslavia and Rwanda which were not established by treaty but by UN Security Council resolutions, and yet they assert their authority over the subjects and officials of those states. ${ }^{39}$ This suggests that there are movements at the international level that are beginning to erode the basis of sovereignty claims. These, however, remain contested and relatively underdeveloped, and it is within the EU that we see the emergence of a right-capacity nexus that most directly threatens an erosion of sovereignty.

The reason for this is because of the peculiar way in which the right-capacity nexus operates within the structures of the EU. Member states have assigned extensive competences - legislative, executive and judicial - to EU institutions. The extent of these competences may not even be dissimilar to that of the federal level of a federal state. What makes the arrangement different from a federation is that the source of EU competences lies in the founding treaties: EU powers are derivative since member states, which possess sole authority to amend the treaties, remaining 'masters of the treaties'. In this respect, the EU remains an entity created under international law. But in other important respects it is, or has evolved into, a novel entity. The ambiguity over its status has remained a principal source of contention.

By virtue of its innovative rulings in the 1960s holding that citizens of member states are able directly to acquire rights from EU law and that EU law has primacy over conflicting provisions in domestic law, the Court of Justice has been able to promote the claim that EU law establishes a unique legal order which is distinct 
from both international and domestic law. ${ }^{40}$ This is significant because, once accepted, member states lose certain controls over EU development. They might continue to regulate competence transfers through treaty amendment and primary rule-making but they cannot control competence creep through innovative rulings of the Court of Justice. The sovereign rights of member states are not simply pooled by consent; they are also curtailed by virtue of 'integration through law' ${ }^{41}$ This dynamic has been driven by the Court's teleological method, which dictates that EU law is interpreted in a manner that promotes continuing European integration (to achieve 'an ever closer union'). Consequently, the capacity of a member state to rule by means of law is restricted by virtue of novel rights and obligations declared by the Court of Justice and which assume priority over domestic law.

The erosion of sovereignty therefore derives from a combination of elements. The sharing of governmental tasks (competences) in itself is not corrosive of sovereignty; these are authorized by member states. Rather, it is the integrationist agenda that has been driven by EU institutions, especially the Commission and the Court, in ways not explicitly authorized by the treaties. This has imposed restrictions on the member states' ability to govern over a broad range of fields in the guise of promoting the 'four freedoms' of goods, services, capital and labour. Of particular significance is that this innovation has been used to promote economic over political freedoms, and using law as an instrument for realizing a liberalizing, de-regulatory agenda. ${ }^{42}$ This instrumentalization of law, without the explicit authorization of member states, suggests the deployment of potentia without potestas. To this extent, it amounts to an erosion of sovereignty. ${ }^{43}$

This issue could be resolved, in theory at least, by bringing legal integration into alignment with political integration. But this solution, which would involve the reconstitution of sovereignty by the formation of a federation or even a federal

40 Van Gend en Loos, above n. 36; Case 6/64 Costa v. ENEL (1964) ECR 585.

41 Mauro Cappelletti, Monica Seccombe and Joseph H.H. Weiler, Integration through Law: Europe and the American Federal Experience (Berlin: de Gruyter, 1985); Karen J. Alter, Establishing the Supremacy of European Law (Oxford: Oxford University Press, 2001). Recent case law asserts the principle that, although the EU is a creation of international law, its own legal order is autonomous and it is able to displace the norms of international law. See, e.g., Opinion 1/09, 2011 ECR I-1137 (the Court of Justice held that the Patent Court established outside the EU institutional framework must respect the 'autonomy of the EU legal order': paras 67); Opinion 2/13 (Accession of the EU to the ECHR), 18 December 2014.

42 Fritz W. Scharpf, Governing in Europe: Effective and Democratic? (Oxford: Oxford University Press, 1999); Vivien A. Schmidt and Mark Thatcher, ed., Resilient Liberalism in Europe's Political Economy (Cambridge: Cambridge University Press, 2013).

43 Cf. Damian Chalmers and Luis Borroso, 'What Van Gend en Loos stands for,' International Journal of Constitutional Law 12 (2014): 105-34 (accepting the 'police logic' of EU law but following Agamben's argument that the essential element of sovereignty is the power over life, arguing that this instrumentalization of law does not erode 'sovereignty'). 
state, ${ }^{44}$ is precisely what most member states and their citizens have not yet been prepared to countenance. While this remains the case, a gulf emerges between sovereignty and the exercise of its marks, the sovereign rights of rule, and this continuing ambiguity and obfuscation signifies an incremental erosion of sovereignty.

One significant check against erosion is found in the rulings of national constitutional courts that seek to protect the basic values of their national constitutions against perceived incursions from EU law. Although national courts mostly accept the principle of the priority of EU law, ${ }^{45}$ they retain the capacity to determine the limits on EU competence transfers by reference to the necessity of preserving basic constitutional rights. ${ }^{46}$ Most active in this endeavour has been the German Federal Constitutional Court (GFCC), which since the 1970s has maintained that the EU is a confederation (Verbund) of sovereign nation-states and therefore an institution whose governing arrangements do not affect sovereignty. ${ }^{47}$ The German constitution (the Basic Law) states that the Federal Republic is a 'democratic and social federal state' in which 'all state authority derives from the people' and this is exercised through elections (Art. 20). The Basic Law provides for participation in the development of the EU, but the EU must be 'committed to democratic, social and federal principles, to the rule of law, and to the principle of subsidiarity' and it must guarantee 'a level of protection of basic rights essentially comparable to that afforded by this Basic Law' (Art. 23). The constitution, by Article 79(3), states that the democratic and federal character of the German state cannot be altered by constitutional amendment.

Although the Basic Law authorizes the transfer by law of 'sovereign powers' [sc. governmental competences] to the EU, the GFCC has held that no transfer of competence that affects the constitutional identity of the German state is permissible and since the 1970s it has been actively policing these transfers. Initially, its attention was drawn to the question of whether the EU paid sufficient regard to

There is, on this analysis, some similarities between the EU and Schmitt's theory of the federation. See Carl Schmitt, Constitutional Theory [1928] (Durham, NC: Duke University Press, 2008), chs 29, 30. But Schmitt treats the federation as serving 'the common goal of political self-preservation of all federation members' (383-4). The federation 'protects its members against the danger of war and against every attack', internally it 'necessarily signifies enduring pacification' (386), and it 'must also be able to decide on the means for the maintenance, preservation, and security of the federation and, if necessary, to intervene' (387). These criteria would suggest that the EU does not meet Schmitt's definition of a federation, not least because the EU lacks the powers of taxation and military force. See further the discussion in section 6 .

45 This had been the ruling of the Italian Constitutional Court in the case of Costa v. ENEL, above $\mathrm{n}$. 40, where the Court, drawing on the analogy with international law, had rejected the principle of priority of EU law. But after the European Court of Justice ruling it subsequently reversed its decision. Recently, however, some national courts have equivocated on the principle of priority.

46 Monica Claes, The National Courts' Mandate in the European Constitution (Oxford: Hart, 2006).

47 See, e.g., IHT v. Einfuhr und Vorratsstelle für Getreide aund Futtermittel [1974] 2 CMLR 540. For the experience in other member states, see Dieter Grimm, 'The Role of National Constitutions in a United Europe,' in Grimm, Constitutionalism: Past, Present and Future (Oxford: Oxford University Press, 2016), ch.13. 
fundamental rights guarantees under the Basic Law and in a series of rulings the Solange decisions and its later judgments on the Maastricht and Lisbon Treaties - the Court reaffirmed the principle of the supremacy of Germany's constitutional rights over EU law. In the Maastricht Treaty case, the Court went further. Maintaining that democracy required the presence of certain pre-legal conditions, such as continuous free debate between opposing social forces, interests and ideas, in which political goals also become clarified and change course', it held that, since the EU lacked such a demos, there were distinct limits to the type and scale of powers that could constitutionally be transferred to the EU. ${ }^{48}$ It also ruled that further powers could be transferred to the EU only if those transfers were approved by the German Parliament (Bundestag) and only if those powers were clearly defined and respected fundamental constitutional rights.

In recent case law, the GFCC has reinforced this position with respect to fundamental rights protection. ${ }^{49}$ But of particular significance with respect to sovereignty claims is its Lisbon Treaty ruling of 2008, where the Court appeared to extend this argument and in effect set certain substantive limits to further EU integration. The Court held that so long as there is no common European demos, EU institutions must respect both the constitutional identity of member states and the core elements of its sovereign powers. It even went so far as to identify those essential 'marks of sovereignty'. Drawing on a distinctively German concept of Staatsaufgabenlehre (the doctrine of state tasks), it identified five areas in which any further transfer of competences would amount to an erosion of sovereignty. These are: (i) the state's monopoly on the use of military and police force; (ii) criminal law; (iii) basic fiscal decisions concerning taxation and public expenditure; (iv) social policy, especially family policy; and (v) cultural policies concerning education, religion, media, art and cultural life. ${ }^{50}$ The Court then declared the need to protect 'sovereign statehood' which it defined as 'a pacified area and the order guaranteed therein on the basis of individual freedom and collective selfdetermination'. 51

These rulings of the GFCC present a strong defence of the sovereign authority of the German nation: the clear message is that, relying on the constituent power of the German people to express the constitutional form of their state, the Court will determine the precise limits of the legitimate authority of the institution of

48 Brunner v. TEU [1994] 1 CMLR 57, para 41.

49 See, e.g., BvGE 99/11, 8 December 2015 (in cases of individual protection of basic rights, in this case relating to the European Arrest Warrant procedure, the GFCC held that it is empowered to review sovereign acts determined by EU law if this is necessary to protect constitutional identity protected by Art. 79(3) of the Basic Law).

50 Note the similarity to Bodin's specification of the 'marks' of sovereignty (text above n. 18). The most significant distinction is that the Court accepts that control of taxation is a mark of sovereignty but silently assumes that monetary policy is not.

51 Lisbon Treaty ruling [2009] BVerfGE 2/08, para 224. 
the EU. ${ }^{52}$ But these legal rulings, as formal elaborations of right, need to be set in context. First, the 'so long as' rulings have in reality provided an incentive for EU institutions to introduce fundamental rights protections and to 'constitutionalize' their arrangements: in this sense the Solange rulings provided an incentive for the constitutionalization of the EU, which serves to enhance its authority and legitimacy. Secondly, although the jurisdiction of the GFCC is regularly invoked whenever the powers of the EU are increased through new treaty provisions, the authority of the EU is extended not simply through formal treaty amendments; as we have seen, extension also takes place as a result of innovative interpretation of the Court of Justice of the EU and that is a more difficult jurisdiction to police. Thirdly, the GFCC has never actually declared any EU measure unconstitutional. Their rulings have always taken the form of 'yes, but': only after the measure before it is held to be valid does the Court go on to issue warnings about further extensions of EU powers. The protective barrier that the Court invariably adopts is to require all new EU measures first to be debated and approved by the Bundestag and it is difficult to see how it can proceed any further with this procedural line of protection. The problem here is that if such rulings amount to 'all bark and no bite', then the existence of this supervisory jurisdiction is in danger of being transformed into the means by which a slow erosion of basic constitutional protections is in fact being legitimated.

\section{The erosion of sovereignty in the Eurozone}

This problem of legitimation by 'yes, but' rulings has now come to a head as a result of the Eurocrisis. The Eurocrisis, which has persisted since 2009, arose because of the global banking crisis of 2007-08, which in turn generated a sovereign debt crisis that has had particularly harsh effects in certain Eurozone countries. The Eurozone had been established on 1 January 1999 in furtherance of a policy of pursuing European Monetary Union and with the adoption of the Euro (currently by 19 of the 28 EU member states), competence on monetary and exchange rate policy was transferred from member states to the European Central Bank (ECB). The crisis arose because the cost of establishing a uniform monetary policy across different national economies had meant that for some (e.g. Germany) credit policies were too tight, while for others (e.g. Portugal, Ireland, Greece, Spain) they were too lax. Consequently, when the 2008 banking crisis produced a credit squeeze, credit flows ceased, national governments were forced to bail out their banks, and within the Eurozone this generated a governmental debt crisis.

That general problem was exacerbated by the austerity measures imposed in response, not least because they have led to a decline in economic growth. As a result, certain Eurozone governments found themselves unable to fund their pro-

52 The German Federal Constitutional Court has not been alone in taking such a stand. See Jan Komárek, 'The place of constitutional courts in the EU,' European Constitutional Law Review 9 (2013): 420-50. 
grammes without substantially increasing their debt levels, thereby exposing structural gaps in government deficit and debt levels that had been hidden in order to meet the strict Maastricht criteria for joining the Euro. The crisis thus revealed a flaw in establishing a monetary union without a fiscal union, that is, of having a common currency while member states retained a central mark of sovereignty - the control of budgetary and tax measures. Consequently, by the end of 2012, and contrary to the 'no-bail out' provision in Art. 125 TFEU, five Eurozone members had been obliged to seek assistance in managing their debt payments.

The European response was to establish a series of financial stability measures: first, in 2010 the European Financial Stability Facility (EFSF), a legal instrument designed to maintain financial stability by providing financial assistance to Eurozone states in difficulty; then in 2011 the European Financial Stabilisation Mechanism (EFSM), which was an emergency funding programme; and finally in 2012 the European Stability Mechanism (ESM), a permanent rescue funding programme designed to succeed the previous temporary arrangements. Under the ESM, which came into effect in January 2013, the budgets of all member states in the Eurozone were required at least to balance, defined as ensuring that any deficit remains less than 3\% of GDP. Any state found not to be in compliance was then obliged to take strict measures, effectively by reducing net public expenditure, to achieve this target.

These arrangements constitute a serious restriction on a critical mark of sovereignty, that of determining taxation and expenditure. In those countries seeking credits, the conditions imposed, which include controls over levels of taxation and a range of domestic social and labour-market policies, have imposed severe budgetary restrictions on governments. This has been most evident in the case of Greece where, faced with extreme austerity conditions, the formal right of the Greek state to withdraw from these European arrangements was tested both in general elections and a referendum and has been shown, on capacity grounds, no longer to be a real right. The episode provides a stark case of a severe erosion of sovereignty, and one which highlights more general issues concerning the governing framework established for the Eurozone.

Of particular significance is the fact that the ESM operates outside the structure of the EU. One result of its growing range of operation is to have distorted the institutional balances in EU governing arrangements. After the UK vetoed the adoption of a new treaty, the Fiscal Compact had to be established as an ordinary intergovernmental treaty, and this has undermined the principle of common evolution by fragmenting the governing arrangements of the Union. ${ }^{53}$ It has resulted in the emergence of an entirely new governmental regime which, in Fritz Scharpf's words, 'establishes a sanctioned European power to direct and control the exercise of national governing powers without regard to the detailed alloca- 
tion of European and national governing functions in Arts. 2-6 TFEU'. ${ }^{54}$ The remarkable reach of its budgetary powers, which were to be introduced 'through provisions of binding force and permanent character, preferably constitutional', 55 imposes a potentially major limit on a key mark of sovereignty. Yet Scharpf claims that this new regime 'is not and cannot be specified in the authorizing legislation' and the exercise of powers under the regime 'is not and cannot be bound to predefined general rules'. 56

These developments have had a considerable impact on the principle of sovereignty. The powers assumed under the Fiscal Compact severely restrict the exercise of those sovereign rights (governmental competences) which the GFCC in its Lisbon Treaty ruling regarded as essential marks of sovereignty. And it is also the case that the governmental response to the crisis has led to the creation of a new type of federal entity operating within the Eurozone. Dawson and de Witte have called this new entity a brand of 'executive federalism'. They argue that it is likely to undermine 'the ability of the EU to mediate conflicting interests' and that it is 'deeply problematic from the perspective of the long-term stability and legitimacy of the Union'. ${ }^{57}$ A particular concern arises because of the uncertain legal basis of these newly-acquired powers. In its controversial ruling in Pringle, the Court of Justice rejected a challenge that the ESM was unlawful because it constituted an exercise in monetary policy, a type of action lies entirely within the EU's exclusive monetary authority. The Court here held that the ESM is a form of economic policy rather than monetary policy, and that this policy had been given separate authority through the Fiscal Compact Treaty. At the same time, the Court also made efforts to regularise the situation by interpreting Art.125 TFEU as imposing a duty on governments to promote 'sound budgetary policy'. ${ }^{58}$ It has, however, been through litigation before the GFCC that the most serious sovereignty challenges have been presented.

Each of the financial stability measures taken by European institutions has been challenged in the GFCC. In its ruling on the Lisbon Treaty, the Court had held that the principle of democracy protected by the Basic Law meant that the Bundestag must determine and maintain accountability for the overall burden of taxation placed on citizens. ${ }^{59}$ Given the German exposure to bailout of weaker economies, which under the ESM was estimated to exceed 704 billion euros, the

54 Fritz W. Scharpf, 'Sovereignty and Democracy in the European Polity: Reflections on Dieter Grimm's Essay, Sovereignty in the European Union,' in Constitutional Sovereignty and Social Solidarity in Europe, ed. Johan van der Walt and Jeffrey Ellsworth (Baden-Baden: Nomos, 2015), 65. TSCG, above n. 53, Art. 3(2).

56 Scharpf, 'Sovereignty and Democracy,' 65.

57 See Mark Dawson and Floris de Witte, 'Constitutional Balance in the EU after the Euro-Crisis,' Modern Law Review 76 (2013): 841, 843.

58 Case C-370-12, Pringle v. Ireland, para 135. For a critical analysis, see Paul Craig, 'Pringle: Legal Reasoning, Text, Purpose and Teleology,' Maastricht Journal of European \& Comparative Law 20 (2013): 1-11.

59 Lisbon Treaty judgment, above n. 48, para 256. 
basic challenge has been that the establishment of these mechanisms undermines one of the basic marks of sovereignty.

In September 2011, the GFCC rejected complaints that the first Euro rescue fund, the EFSF and other measures which authorized the bail-outs for Greece, Ireland and Portugal, breached these protections, holding that these fund arrangements did not amount to a sufficiently large financial commitment as to threaten the budgetary autonomy of the Bundestag. In February 2011, the Court issued another judgment on the EFSF, maintaining that it was unconstitutional to delegate all decisions on EFSF participation to a Budget Committee of the Bundestag and that, as a matter of principle, the entire Bundestag must approve Germany's involvement in the mechanism. And when the mechanism was given permanent form in the ESM adopted in July 2012, its implementation had to be postponed until the Court in September 2012 had confirmed in principle the legality of the arrangement. At that point, the Court refused an injunction that would have prevented ratification of the Fiscal Compact Treaty, but in summer 2013 it began hearing arguments on the substantive issue of the ECB's power to engage in selective purchase of Eurozone government bonds on the secondary markets, the socalled Outright Monetary Transactions (OMT) programme.

In January 2014, the Court held that, unless interpreted in a highly restrictive manner, the ECB's OMT programme lacked an adequate legal basis and that it also violated certain key aspects of Germany's constitutional identity as a sovereign democratic state. It then, for the first time in its history, made a preliminary reference to the Court of Justice. ${ }^{60}$ The critical issue was whether OMT is to be construed as an exercise of economic or monetary policy and if the latter whether, contrary to Art.123 TFEU, it violated the prohibition of monetary financing of the budget. On 16 June 2015, in the Gauweiler case, the Court of Justice ruled that under the Treaties the OMT programme was lawful. ${ }^{61}$ Following the method deployed in Pringle, which assumed that whether a measure is one of economic or monetary policy is to be determined by its objective rather than its effect, the Court held that in this case, since the OMT measures were intended to maintain price stability, the primary objective fell into the category of monetary policy. Giving considerable deference to the ECB's technical assessments, the Court also undertook a light proportionality review and held that the measure met the tests of suitability and necessity.

This ruling placed the issue back with the GFCC and in its ruling of 21 June 2016 the Court, once again, backed down. Although maintaining that the lack of democratic legitimation implied by the ECB's independence should lead a court to engage in a strict review of its mandate, the GFCC nevertheless held that, provided the conditions laid down in the Court of Justice's ruling were complied with,

60 BVerfG E 2728/13 (14 January 2014). For commentary, see the 2014 Special Issue of the German Law Journal, vol. 15, no. 2, http://www.germanlawjournal.com/volume-15-no-02.

61 Case C-62/14 Gauweiler. For commentary, see the 2015 Special Section of the German Law Journal, vol. 16, no. 4, http://www.germanlawjournal.com/volume-16-no-04. 
the provisions of the Basic Law concerning constitutional identity were not violated.

The Pringle and Gauweiler cases throw into relief the limitations imposed on courts in policing the legality of technical areas of governmental action. But they also demonstrate the role that courts are able to perform in providing 'normative legitimization to the austerity model' being pursued within Eurozone governance and of legitimizing the ECB's role 'not only in monetary policy but also in shaping the general economic policy of the Union'. ${ }^{62}$ They therefore provide illustrations of a general proposition that, although positive law might occupy a relatively independent domain, the court is likely to lose that autonomy the closer it intrudes on fundamental political matters. Such basic political questions, it has been claimed, ultimately 'can neither be decided by a previously determined general norm nor by the judgment of a disinterested and therefore neutral third party'. ${ }^{63}$ But if they provide further examples of the manner in which law is being instrumentalized as potentia without attending to the conditions of rightful authority implied by potestas, what does this signify about sovereignty in Eurozone governance?

Some might say that these developments demonstrate that the EU governmental network is now asserting a sovereign power to determine the existence of an exceptional situation and to exercise the power perceived to be necessary to provide an effective response. ${ }^{64}$ Others might even suggest that the exceptional has now been normalized and that we have either entered into an altogether new phase of sovereignty, ${ }^{65}$ or that this degree of governmentalization of the state operates contrary to any logic of sovereignty and therefore amounts to its eclipse. ${ }^{66}$ Although there is powerful evidence to support these various claims, the situation presently remains quite fluid. And while this remains the case, it seems better to characterize the development of Eurozone governance as a striking illustration of a contemporary erosion of sovereignty. Journal of European \& Comparative Law 23 (2016): 39.

63 Carl Schmitt, The Concept of the Political, 27.

64 Carl Schmitt, Political Theology, 12: 'What characterizes an exception is principally unlimited authority, which means the suspension of the entire existing order. In such a situation it is clear that the state remains, whereas law recedes. Because the exception is different from anarchy and chaos, order in the juristic sense still prevails even if it is not of the ordinary kind'.

65 See Damian Chalmers, 'European Restatements of Sovereignty,' in Sovereignty and Law: Domestic, Regional and International Perspectives, ed. Richard Rawlings, Peter Leyland and Alison L. Young (Oxford: Oxford University Press, 2013), ch.11. Chalmers explains three ways of thinking about sovereignty, with the third being that of European sovereign government in which EU government acquires sovereign powers of rule (206-11). See further Damian Chalmers, 'Crisis reconfiguration of the European constitutional state,' in The End of the Eurocrats' Dream: Adjusting to European Diversity, ed. Damian Chalmers, Markus Jachtenfuchs and Christian Joerges (Cambridge: Cambridge University Press, 2016), 266-98.

See Foucault, Security, Territory, Population, 286. 


\section{Conclusion}

In modern public law discourse, sovereignty signifies the autonomy of the political domain and provides the medium though which the idea of absolute legal authority can be grasped. This concept has been much misunderstood and this has come to light in recent years when, as a result of changes in the nature of the activity of governing, scholars have sought its re-specification. Sometimes this stems from the conflation of sovereignty with the figure of the sovereign, sometimes from the conflation of sovereignty and government. The responses have varied, but they all tend to be variations of an attempt to sever its legal and political dimensions.

Some scholars have sought to rework sovereignty as a purely formal legal concept and establish the 'sovereignty of law' in ways that ignores its political aspects. Others have argued that the emergence of an intricate governmental apparatus is indicative of a fracturing or dividing of sovereignty and the emergence of a political world of post-sovereignty. The former is a pipe-dream and the latter seems to envisage not so much the emergence of a new political world as the destruction of the political world. This is so because if sovereignty is eclipsed then the notion of public law - public law understood as the juridical expression of the autonomy of the political domain - disintegrates. What will remain is a much governed world, but one which follows its own structural imperatives shorn of a political imaginary that conceives authority as founded on some notion of collective self-actualization.

Once the world of the political is envisioned as a series of collective action problems to be mediated through a combination of market mechanisms, the aggregation of individual self-interest and expert knowledge, then Duguit's 'scientific' claims - albeit shorn of its progressive undertones - will have come to pass. Destroy the symbolic and we destroy the political, because in order to grasp the nature of political experience 'we need more than the philosopher's conception of reason, and more than the economist's conception of interest'. ${ }^{67}$ To grasp the idea of the political as a world in which individuals are prepared to make sacrifices for the good of their state we also 'will need more than the communitarian's idea of community'. ${ }^{68}$ There is little doubt that the changes in the nature of governing presently taking place within the European sphere are imposing strains on the modern political imaginary founded on the concept of sovereignty. But this is not yet sufficient reason to abandon the modern idea of sovereignty and rightcapacity nexus that lies at that concept's core. 